\title{
EFEKTIVITAS EKSTRAK DAUN SIRSAK (ANNONA MURICATA L) TERHADAP KADAR IL-10 PADA MAMMAE TIKUS BETINA SPRAGUE DAWLEY YANG DIINDUKSI STAPHYLOCOCCUS AUREUS
}

\author{
Asmiati \\ Program Studi D-III Kebidanan, STIKES Graha Medika, Jl. Raya AKD,RSI Moonow Lt.2, Mongkonai \\ Barat, Kota Kotamobagu, asmisyma@gmail.com
}

Diterima 28 Desember 2019, disetujui 16 April 2020, diterbitkan 30 April 2020

Pengutipan: Asmiati. (2020). Efektivitas Ekstrak Daun Sirsak (Annona Muricata L) Terhadap Kadar Il-10 Pada Mammae Tikus Betina Sprague Dawley Yang Diinduksi Staphylococcus Aureus.Gema Wiralodra, Vol 11, No 1, Hal 74-81, April 2020

\begin{abstract}
ABSTRAK
Senyawa kimia yang terkandung dalam tanaman daun sirsak yaitu flavonoid, tanin, fitosterol, kalsium oksalat, alkaloid dan acetogenin. Penelitian ini bertujuan mengetahui efektivitas ekstrak daun sirsak (Annona muricata L) terhadap kadar IL-10 pada mammae tikus betina sprague dawley yang diinduksi bakteri staphylococcus aureus. Penelitian ini menggunakan jenis penelitian true experimental dengan rancangan post-test Only Control Grup Design. Sampel penelitian ini adalah tikus betina Sprague dawley dengan berat badan 200 - 250 gram sebanyak 20 ekor yang dibagi menjadi 4 kelompok (masing-masing 5 ekor), yaitu kelompok kontrol, kelompok perlakuan 1, kelompok perlakuan 2 dan kelompok perlakuan 3 yang diberikan treatment selama 5 hari. Semua kelompok diinduksi Staphylococcus aureus $0.2 \mathrm{ml}$ x $10^{7} \mathrm{ml} / \mathrm{CFU}$. Pemeriksaan kadar IL-10 menggunakan metode R \& D system Elisa Rat. Penganalisisan data menggunakan uji Anova + posthoc dengan nilai signifikansi $\mathrm{p} \leq 0.05$ dan CI 95\%. Hasil penelitian menunjukkan bahwa ada perbedaan kadar sitokin IL-10, baik pada kelompok kontrol maupun pada semua kelompok perlakuan setelah diberikan treatment dengan nilai $\mathrm{p}<0,05$. Hal ini menunjukkan bahwa ada perbedaan kadar IL-10 setelah diberikan perlakuan antar semua kelompok. Peningkatan kadar IL10 yang lebih besar terjadi pada kelompok perlakuan 1 (Ekstrak daun sirsak tunggal) (rerata $\pm 45,8$ $\mathrm{pg} / \mathrm{ml}$ ) dibandingkan dengan kelompok kontrol (rerata $\pm 15,5 \mathrm{pg} / \mathrm{ml}$ ), kelompok perlakuan 1 (rerata $\pm 40,0 \mathrm{pg} / \mathrm{ml})$ dan perlakuan $3($ rerata $\pm 30,0 \mathrm{pg} / \mathrm{ml})$.
\end{abstract}

Kata kunci: Kadar IL-10, ekstrak daun sirsak, Staphylococcus aureus

\begin{abstract}
Chemical compounds contained in soursop leaf plants are flavonoids, tannins, phytosterols, calcium oxalate, alkaloids and acetogenin. This study aims to determine the effectiveness of soursop leaf extract (Annona muricata L) on IL-10 levels in mammary sprague dawley mice induced by staphylococcus aureus bacteria. This study used true experimental research with a posttest design Only Control Group Design. The sample of this study was Sprague Dawley female rats with a weight of 200-250 grams as many as 20 birds which were divided into 4 groups (5 each), namely the control group, treatment group 1, treatment group 2 and treatment group 3 which were given treatment during 5 days. Soursop plants are obtained from Jeneponto Regency, South Sulawesi. All groups were induced by Staphylococcus aureus $0.2 \mathrm{ml}$ x $108 \mathrm{ml} / \mathrm{CFU}$. Examination of IL-10 levels using the Elisa Rat R \& D system method. Analyzing the data using ANOVA + posthoc test with a significance value of $p \leq 0.05$ and CI 95\%. The results showed that there were differences in IL-10 cytokine levels, both in the control group and in all treatment groups after being given treatment with a value of $p<0.05$. This shows that there are differences in IL-10 levels
\end{abstract}

Diterbitkan oleh:

Universitas Wiralodra

Jln. Ir. H. Juanda Km 3 Indramayu, Jawa Barat 
after being given treatment between all groups. A greater increase in IL-10 levels occurred in the treatment group 1 (single soursop leaf extract) (mean $\pm 45.8 \mathrm{pg} / \mathrm{ml}$ ) compared to the control group (mean $\pm 15.5 \mathrm{pg} / \mathrm{ml}$ ), treatment group 1 (mean $\pm 40.0 \mathrm{pg} / \mathrm{ml}$ ) and treatment 3 (mean $\pm 30.0 \mathrm{pg} /$ $\mathrm{ml})$.

Keywords: IL-10 levels, soursop leaf extract, Staphylococcus aureus

\section{PENDAHULUAN}

Salah satu tanaman obat yang sering digunakan oleh masyarakat untuk mengobati radang atau inflamasi adalah daun sirsak (Rahmawati, Rahman and Mustari, 2012). Sirsak (Annona muricata L.) merupakan tanaman yang tumbuh di berbagai belahan dunia, terutama di negara-negara tropis (Maramis, Kaseke and Tanudjadja, 2014). Selain itu daun sirsak secara empirik juga telah digunakan oleh masyarakat untuk pengobatan tradisional (Hussaana, Djam'an, and Goenarwo 2015; Bento et al. 2013).

Senyawa kimia yang terkandung dalam tanaman daun sirsak yaitu flavonoid, tanin, fitosterol, kalsium oksalat, alkaloid dan acetogenin. Flavonoid merupakan senyawa polifenol yang terdapat pada tumbuhan yang memiliki efek biologis seperti antimikroba, antiviral, antihipertensi, antioksidan, antiplatelet, sitotooksik, dan anti-inflamasi (Rathee et al., 2009). Senyawa acetogenin yang ditemukan pada daun sirsak bermanfaat mengobati berbagai penyakit (Puspitasari et al., 2016).

Beberapa penelitian telah dilakukan pada daun sirsak yang meliputi efektivitas ekstrak daun sirsak dalam menurunkan kadar TNF- $\alpha$ dan meningkatkan kadar NO Uji coba pada mencit swiss yang hasil penelitiannya menunjukkan bahwa kelompok yang mendapatkan perlakuan ekstrak daun sirsak pada dosis $100 \mathrm{mg} / \mathrm{kgBB} /$ hari didapatkan kadar TNF- $\alpha$ lebih rendah dibandingkan dosis $200 \mathrm{mg} / \mathrm{kgBB}$ tanpa inokulasi (Estela et al., 2016). Penelitian lain juga menunjukkan bahwa uji daya anti bakteri ekstrak etanol daun sirsak terhadap pertumbuhan bakteri Staphylococcus aureus dan kesetaraannya dibandingkan dengan amoxicylin trihidrat yang hasil penelitiannya menunujukkan dengan menggunakan pelarut etanol $70 \%$ dan konsentrasi ekstrak etanol daun sirsak 10\%,20\%,40\% dan 60\% dapat menghambat pertumbuhan bakteri Staphylococcus aureus (Tampubolon, 2001). Penelitian yang sama juga dilakukan oleh (Meisyayati and Dewiwaty, 2015), yaitu efektivitas anti-inflamasi ekstrak daun sirsak sebagai konplemen Natrium diklofenak pada tikus putih jantan galur wistar yang hasilnya menunujukkan 
bahwa pemberian natrium diklofenak tunggal dosis $4,5 \mathrm{mg} / \mathrm{kgBB}$, ekstrak daun sirsak tunggal dosis $100 \mathrm{mg} / \mathrm{kgBB}$ serta daun sirsak sebagai komplemen natrium diklofenak pada dosis setengah dan seperempat dari dosis tunggal masing-masing komponen menunjukkan adanya efek antiinflamasi pada keempat kelompok tersebut.

Berdasarkan kejadian mastitis yang cukup tinggi baik pada ibu nifas atau ibu menyusui maka diperlukan terapi atau pengobatan. Guna mengatasi hal tersebut, salah satu tanaman yang dapat dijadikan sebagai anti inflamasi terhadap penyakit mastitis yaitu daun sirsak. Pada dewasa ini masyarakat sudah semakin selektif pada proses pengobatan dengan menggunakan obat-obatan kimiawi, dengan alasan adanya efek samping yang kadang ditimbulkan. Sebagian besar menarik minat masyarakat ketika melihat produk-produk obat yang alami dan terbuat dari tanaman-tanaman obat tradisional. Penelitian tentang daun sirsak sebagai anti-inflamasi pada mastitis belum pernah dilakukan sebelumnya. Oleh karena itu, penelitian ini dilakukan untuk melihat efektivitas ekstrak daun sirsak (Annona muricata L.) terhadap kadar IL-10 pada mammae tikus betina strain Sprague Dawley yang diinduksi bakteri Staphylococcus aureus.

\section{METODE PENELITIAN}

\section{Rancangan Penelitian}

Jenis penelitian yang digunakan dalam penelitian ini adalah true experimental atau eksperimen murni yaitu percobaan pada laboratorium, dengan rancangan post-test Only Control Grup Design. Percobaan dilakukan pada tikus strain Sprague dawley dengan berat 200-250 gram sebanyak 20 ekor. Kelompok dibagi menjadi 4 (empat) kelompok yaitu kelompok Kontrol negatif, kelompok perlakuan I (kontrol positif), kelompok perlakuan II( ekstrak daun sirsak) dan perlakuan III (ekstrak daun sirsak kombinasi antibiotik Cefadroxil).

\section{Populasi dan Teknik Sampel}

Populasi dalam penelitian ini adalah tikus strain sprague dawley dengan berat badan 200-250 gram sebanyak 20 ekor. Sampel dalam penelitian ini adalah tikus strain Sprague dawley dengan berat 200-250 gram sebanyak 20 ekor, namun dilakukan pengelompokan secara acak untuk menghindari bias karena faktor umur. Penarikan sampel

Diterbitkan oleh: 
dilakukan berdasarkan uji coba research guidelines for evaluating the savety and efficaty of herbal medicine sesuai dengan standar WHO (Word Healts Organization) yaitu minimal 5 (lima) ekor tikus strain sprague dawley pada masing-masing kelompok. Sebelum diberikan treatment semua kelompok diinduksi bakteri Staphylococcus aureus ( $2 \times 10^{7}$ $\mathrm{CFU} / \mathrm{ml}$ ) selama 1 x 24 jam yang dibagi menjadi 4 kelompok.

\section{Analisis data}

Data diolah dan dianalisis dengan bantuan komputer. Efektivitas pemberian ekstrak daun sirsak, kadar sitokin IL-10 ditampilkan dalam bentuk mean \pm (standar deviasi) dengan confidence interval (95\% CI). Apabila data terdistribusi normal dilakukan Uji bivariate menggunakan paired sample T test untuk melihat perbedaan kadar sitokin IL- 10 pada kelompok kontrol negatif, perlakuan 1, perlakuan II dan perlakuan III setelah diberikan perlakuan. Selain itu, Uji one way ANOVA juga dilakukan untuk melihat perbedaan kadar sitokin IL-10 antar kelompok dan dilanjutkan dengan anlisis post hoc LSD.

\section{HASIL}

Berdasarkan hasil penelitian diperoleh bahwa pada hari ke-3 setelah induksi S.aureus, nilai rerata kadar IL-10 kelompok yang tidak diberikan apa-apa (kontrol negatif) sebesar $\pm 52,5 \mathrm{pg} / \mathrm{ml}$. Sedangkan nilai rerata kadar IL-10 kelompok perlakuan dengan pemberian antibiotik cefadroxil meningkat hampir dua kali lipat dibanding kontrol negative $( \pm 82,1 \mathrm{pg} / \mathrm{ml})[p=0,078]$. Pada kelompok yang diberikan ekstrak daun sirsak diperoleh nilai rerata kadar IL-10 jauh lebih tinggi dibandingkan dengan kontrol negatif $( \pm 93,4 \mathrm{pg} / \mathrm{ml})$, perbedaannya pun hampir dua kali lipat dibandingkan kontrol negatif, apabila ekstrak daun sirsak dikombinasi dengan antibiotik cefadroxil yang diberikan selama 3 hari setelah induksi S.aureus, nilai rerata kadar IL-10 sebesar $\pm 95,9$ pg/ml, dua kali lipat bertambah dibandingkan kelompok kontrol negatif. Hal ini dimungkinkan bahwa treatment yang diberikan belum memiliki efek atau treatment yang dilakukan belum maksimal.

Berdasarkan hasil penelitian diperoleh bahwa pada hari ke-7 setelah induksi S.aureus, nilai rerata kadar IL-10 kelompok yang tidak diberikan apa-apa (kontrol negatif) yaitu $\pm 72,4 \mathrm{pg} / \mathrm{ml}$, lebih tinggi jika dibandingkan dengan 3 hari setelah induksi ( $\pm 52,5$

Diterbitkan oleh: 
$\mathrm{pg} / \mathrm{ml}$ ). Setelah diberikan antibiotik cefadroxil nilai rerata kadar IL-10 meningkat dua kali lipat $( \pm 142,3 \mathrm{pg} / \mathrm{ml})$ dibanding dengan rerata kontrol negatif $( \pm 72,4 \mathrm{pg} / \mathrm{ml})[p=0,006]$. Begitupula pada kelompok yang diberikan ekstrak daun sirsak reratanya jauh berbeda dibanding dengan kontrol negatif $( \pm 168,7 \mathrm{pg} / \mathrm{ml})[p=0,000]$. Begitu pun ketika ekstrak daun sirsak dikombinasi antibiotik cefadroxil juga mengalami peningkatan dibanding dengan rerata kontrol negative $( \pm 159,5 \mathrm{pg} / \mathrm{ml})[p=0,001]$. Jadi antara kelompok antibiotic cefadroxil, ekstrak daun sirsak, dan kombinasi ekstrak daun sirsak dan antibiotik dibandingkan dengan kontrol negatif hasil pengukuran kadar IL-10 berbeda $(p=0,002)$.

Tabel Rerata perbedaan kadar IL-10 pada masing-masing kelompok pada hari ke-7

\begin{tabular}{|c|c|c|}
\hline $\begin{array}{l}\text { Kelompok } \\
\text { Sampel } \\
\qquad(\mathrm{n}=5)\end{array}$ & $\begin{array}{c}\text { Kadar IL-10 }(\mathrm{pg} / \mathrm{ml}) \\
\text { Hari ke } 7 \\
\text { Mean } \pm \text { SD } \\
\end{array}$ & Nilai $p$ \\
\hline $\begin{array}{c}\text { Kelompok I } \\
\text { (kontrol negatif) } \\
\text { Kelompok II } \\
\text { (kontrol positif) }\end{array}$ & $72,4 \pm 15,5$ & $0,022^{\mathrm{a}}$ \\
\hline $\begin{array}{c}\text { (Antibiotik } \\
\text { Cefadroxil 45mg/kg } \\
\text { BB/12 jam) }\end{array}$ & $142,3 \pm 40,0 *$ & $0,011^{\mathrm{a}}$ \\
\hline $\begin{array}{c}\text { Kelompok III } \\
(\mathrm{ekstrak} \text { daun } \\
\text { sirsak } 100 \mathrm{mg} / \mathrm{kgBB} / \mathrm{hr})\end{array}$ & $168,7 \pm 45,8^{*}$ & $0,025^{\mathrm{a}}$ \\
\hline $\begin{array}{r}\text { Kelompok IV } \\
\text { (ekstrak daun }\end{array}$ & $159,5 \pm 30,0^{*}$ & $0,006^{\mathrm{a}}$ \\
\hline $\begin{array}{l}\text { *ANOVA } \\
\text { aRepeated Anova }\end{array}$ & & \\
\hline
\end{tabular}

\section{Pembahasan}

Peningkatan rerata kadar IL-10 dimungkinkan terkait dengan mekanisme kerja antibiotik cefadroxil dalam membunuh bakteri S.aureus dengan cara menghambat sintesis

Diterbitkan oleh: 
dinding sel bakteri, protein bakteri, protein asam nukleat bakteri dan menghambat jalur metabolisme utama bakteri. Materi genetik bakteri yang ada didalamnya terurai akibat mekanisme kerja antibiotik cefadroxil dan menyebabkan bakteri mati sehingga inflamasi menurun dan kadar IL-10 meningkat ( antiinflamasi meningkat) (Nester et al., 2009).

Begitupula pada kelompok yang diberikan ekstrak daun sirsak reratanya jauh berbeda dibanding dengan kontrol negatif $( \pm 168,7 \mathrm{pg} / \mathrm{ml}) \quad[p=0,000]$. Hal ini dimungkinkan karena ektrak daun sirsak mengandung senyawa bioaktif diantaranya flavonoid, saponin, alkaloid, dan tannin yang berfungsi sebagai anti inflamasi. Senyawa flavonoid merupakan suatu kelompok fenol yang terbesar yang ditemukan di alam. Flavonoid bekerja pada endothelium mikrovaskular untuk mengurangi terjadinya hipermeabilitas dan radang. Beberapa senyawa flavonoid dapat menghambat pelepasan asam arakhidonat dan sekresi enzim lisosom dari membran dengan jalan memblok jalur siklooksigenase (COX) dan jalur lipoksigenase sehingga menurunkan kadar prostaglandin dan leukotriena (mediator inflamasi). Prostaglandin sangat berperan pada patogenesis inflamasi (Rathee et al. 2009; Panche. 2016).

Respon inflamasi meningkat pada kejadian mastitis yang ditandai adanya sel-sel radang yang berada disekitar sel epitel dan jaringan payudara, sitokin IL-10 sebagai antiinflamasi akan melakukan pertahanan terhadap host terutama pada bagian sel-sel epitel dan jaringan payudara untuk mengurangi kerusakan sel, menghambat aktivitas peradangan dan respon kekebalan tubuh. Sitokin IL-10 memainkan peran sentral dalam membatasi respon imun inang terhadap berbagai patogen dan menjaga homeostasis jaringan normal.

Peningkatan IL-10 dapat mencegah perkembangan lesi imunopatologis yang terjadi dari respon kekebalan protektif terhadap infeksi akut dan kronis. Sitokin IL-10 sangat penting untuk perawatan integritas dan homeostasis lapisan jaringan sel epitel dan memfasilitasi proses penyembuhan jaringan luka, infeksi atau pembengkakan (Jean 2007 ;Wenjun 2011).

Pemberian antibiotik dan terapi komplementer ekstrak daun sirsak dapat menghambat sintesis dinding bakteri, sehingga lisis dan mengurangi reaksi peradangan yang terjadi. Berdasarkan uraian di atas peneliti berasumsi ekstrak daun sirsak dapat dijadikan sebagai terapi komplementer dalam penanganan mastitis karena mampu 
meningkatkan kadar IL-10 yang berperan sebagai antiinflamasi sehingga dapat menekan reaksi iniflamasi yang terjadi saat terpapar oleh mikroorganisme.

\section{KESIMPULAN DAN SARAN}

Berdasarkan hasil dan pembahasan maka dapat disimpulkan bahwa ekstrak daun sirsak (Annona muricata L) dapat meningkatkan kadar sitokin IL-10 pada mammae tikus betina strain Sprague Dawley yang diinduksi bakteri staphylococcus aureus. Peningkatan kadar IL-10 sangat terlihat pada hari ke-6 pada kelompok perlakuan dibanding kelompok kontrol. Jadi ekstrak daun sirsak menunjukkan bahwa dapat menekan inflamasi dan dapat meningkatkan anti-inflamasi, sehingga ekstrak daun sirsak dapat dijadikan sebagai terapi komplementer terhadap inflamasi karena dapat meningkatkan kadar IL-10. Bagi peneliti selanjutnya diharapkan untuk melakukan uji kuantitatif ekstrak daun sirsak terlebih dahulu.

\section{UCAPAN TERIMAKASIH}

Dalam penyusunan tesis ini tidak terlepas dari berbagai pihak. Peneliti secara khusus mengucapkan terima kasih yang sebesar-besarnya kepada semua pihak yang telah membantu terkhusus Yayasan Graha Medika yang telah mensuport.

\section{DAFTAR PUSTAKA}

Bento, E. B., Matias, E. F. and Brito, F. E. (2013) 'Hubungan Makanan Dan Obat: Antimikroba dan Kegiatan sinergis of sirsak L.', International Journal of Food Properties, 16, pp. 738744. doi: 10,1080 / 10942912.2011.565905.

Estela, M. et al. (2016) 'Efektivitas Ekstrak Daun Sirsak (Annona Muricata) dalam Menurunkan Kadar TNF $\alpha$ dan Meningkatkan Kadar NO Uji Coba pada Mencit Swiss yang Diinokulasi Plasmodium Berghei ANKA', Jurnal Kedokteran Brawijaya, 29(1), pp. 39-42.

Hussaana, A., Djam'an, Q. and Goenarwo, E. C. (2015) 'Ekstrak Daun Sirsak (Annona muricata) Sebagai Penghambat Perkembangan Tumor Payudara', Journal Of Pharmaceutical Science And Pharmacy Practice, 2(2), pp. 41-44.

Jean, P. (2007) 'Saponins, Classification And Occurence In The Plant Kingdom. Phytochemistry', 68, pp. 275-297. doi: 10.1016/j.phytochem.2006.10.008.

Maramis, R., Kaseke, M. and Tanudjadja, G. N. (2014) 'Gambaran Histologi Aorta Tikus Wistar Dengan Diet Lemak Babi Setelah Pemberian Ekstrak Daun Sirsak(Annona muricata L)', Jurnal e-Biomedik (eBM), 2(2), pp. 431-435.

Meisyayati, S. \& Dewiwaty, M. (2015) 'Efektifitas Antiinflamasi Ekstrak Daun Sirsak Sebagai

Diterbitkan oleh:

Universitas Wiralodra

Jln. Ir. H. Juanda Km 3 Indramayu, Jawa Barat 
Komplemen Natrium Diklofenak Pada Tikus Wistar Jantan', UNJANI, 3(2), pp. 18-21.

Nester, E. . et al. (2009) 'Microbiology A Human Perspective (6th Edition ed.)', Journal Of McGraw-Hill.

Panche, et. a. (2016) 'Flavonoids: An Overview.', Jurnal Of Nutritional Science. doi: 10.1017/jns.2016.41.

Puspitasari, M. L. et al. (2016) 'Aktivitas Antioksidan Suplemen Herbal Daun Sirsak (Annona muricata L.) dan Kulit Manggis (garcinia mangostana L.)', Jurnal Pangan dan Agroindustri, 4(1), pp. 283-290.

Rahmawati, Rahman, S. and Mustari (2012) 'Uji Efek Antiinflamasi Ekstrak Etanol Daun Sirsak (Annona muricata Linn.) Terhadap Mencit (Mus Musculus) Jantan Yang Diinduksi Dengan Karagen', As-Syifaa, 4(1), pp. 7-15.

Rathee, P. et al. (2009) 'Mechanism of Action of Flavonoids as Anti-inflammatory Agents: A Review', Bentham Science Publishers Ltd., 8(3), pp. 229-234.

Tampubolon, A. (2001) 'Uji Daya Anti Bakteri Ekstrak Etanol Daun Sirsak (Annona muricata L) Terhadap Pertumbuhan Bakteri Staphylococcus aureus dan kesetaraannya Dibandingkan Dengan Amoxicilin Trihidrat', Farmasi Universitas Surabaya.

Wenjun, O. et al (2011) 'Regulation and Functions of the IL-10 Family of Cytokines In Inflamation and Disease.' doi: 10.1146/annurev-immunol-031210-101312. 